\title{
App Development for Enterprises Financial Insolvency Diagnostic with Legal Support
}

\author{
Anatoly Pozmogov ${ }^{1}$, Ruslan Omarov ${ }^{2}$, Sergei Shlykov ${ }^{2}$, Larisa Badova ${ }^{1}$, Albina Tokaeva $^{3}$ \\ ${ }^{1}$ Financial University under the Government of the Russian Federation, Vladikavkaz branch, Russia, \\ pozmogov@bk.ru \\ ${ }^{2}$ Stavropol State Agrarian University, Russia, doooctor@yandex.ru \\ ${ }^{3}$ North Ossetian State University named after K. L. Khetagurov, Russia, to.alb@yandex.ru
}

\begin{abstract}
Bankruptcy issues of legal entities by the current federal law are relevant for business entities engaged in commercial activities. One of the options for solving financial difficulties in settling with creditors is the bankruptcy of a legal entity. Studying the prerequisites for bankruptcy is one of the factors for the effective functioning of any company. One of the signs of loss of solvency is the loss of solvency. In this regard,цy developed models for assessing the risks of financial insolvency (bankruptcy) of organizations, create an application the VBA MS Excel to simplify, accelerate, and analyze. In the theoretical part, it is noted that foreign experience in practice is carried out between the conditions of insolvency and bankruptcy, understanding the bankruptcy of the debtor, satisfied by the judicial authority. The article examines the economic essence of the concept of "bankruptcy", provides step-by-step instructions for such a legal entity, and the possible consequences of the financial crisis. An analysis of an economic entity based on a rating assessment, which can provide information on how to get out of a crisis state or go through the procedure for overcoming a bankruptcy crisis. The authors substantiate the use of several methods used to assess the risk of company bankruptcy, which leads to a significant increase in the objectivity of the results.
\end{abstract}

Key words: application,VBA MS Excel, financial difficulties, bankruptcy.

\section{INTRODUCTION}

The study of the premises to bankruptcy is one factor for the effective functioning of any company. One of its signs is the loss of solvency. The grounds for the occurrence of this obligation are in the form of civil transactions or circumstances provided for by civil law, for example, as causing harm, unjust enrichment.

It is noted that foreign experience has, in practice, distinguished between the terms of insolvency and bankruptcy, understanding as insolvency the absolute insolvency of the debtor satisfied by the judicial authority [1].
Absolute insolvency (insolvency) differs from relative or practical bankruptcy, the basis of which is the temporary absence or shortage of cash necessary for the debtor on the day when the payment is due.

The basis of legislation on insolvency is constituted by the provisions of the Constitution and Civil Code of the Russian Federation (parts I and II), which contain rules on recognition of debtors as bankrupt and the forced seizure their property in favor of creditors, as well as Federal Law No. 127-FL"On Insolvency (Bankruptcy)" with taking into account changes and additions that were introduced by Federal Law No. 482-FL [2].

Federal Law No. 127-FL"On Insolvency (Bankruptcy)" (from now on - the Law on Insolvency (Bankruptcy) considers the concept of insolvency (bankruptcy) as the absolute impossibility of making a payment by a debtor for obligations undertaken by creditors and personnel of the enterprise.

Debts of a legal entity, which are calculated in non-monetary assets, can be recovered by creditors only through a court.

The amendments that were introduced by the Federal Law No. 482-FL dated December 29, 2014, to the Law on Insolvency (Bankruptcy) stipulate the prohibition of the choice of an arbitration manager if the debtor himself initiates proceedings. Also, Federal Law No. 482-FL amended the procedure for declaring a legal entity bankrupt by banks [9].

The main sign of insolvency (bankruptcy) of the organization's agricultural organizations is the lack of funds to pay off debts to creditors. If financial difficulties continue for more than three months, then there is every reason to initiate bankruptcy proceedings of a legal entity [3].

Bankruptcy procedures for a legal entity include several stages in Russian law.

Stage 1. The procedure for monitoring (observing) bankruptcy of a legal entity.

The second stage is financial recovery or rehabilitation.

The third stage is external management, the procedure used in the bankruptcy case against the debtor to restore its solvency.

If the organization has a chance to restore solvency, then the decision on external management is taken as the next measure after financial recovery. 
At this stage of the bankruptcy procedure, management, and full management of all processes rest with the external manager [12].

The fourth stage of the process is bankruptcy proceedings.

Stage 5 - the conclusion of a settlement agreement.

To conduct bankruptcy proceedings, it is necessary to conduct a thorough analysis of the financial condition of the organization.

The initiator of a conflict-free resolution of problems can be any of the parties.

Thus, conducting bankruptcy proceedings is a rather complicated, multi-stage process, which requires interdisciplinary knowledge and skills mastered by future arbitration managers in the framework of a unique retraining program [4].

For a favorable outcome of a bankruptcy case with minimal costs, it is better to prepare for the procedures in advance, involving experts and professional anti-crisis managers with exceptional knowledge and the necessary experience.

\section{MATERIALS AND METHODS}

In the context of informatization and digitalization, the need for reliable information on the financial viability of an economic entity significantly increases. It will give an interested user to judge the degree of investment attractiveness, provide an opportunity for company executives to be confident in the future. Quantitative and qualitative analysis of economic activity can be carried out based on the indicators of accounting (financial) statements. The rating also helps owners to identify specific development trends, understand the company's future strategy. Therefore, the selected methodological approach to the analysis of the financial condition of the organization is an integral part of economic analysis. It allows you to make a particular conclusion about the results of the organization, to identify strengths and weaknesses [6]. The relevance of this area is that the final rating score takes into account all the most critical parameters of the financial and operating activities of the company, i.e., economic activity in general, which is necessary for a market economy [10].

Financial analysis is a long and complicated process that has its technology for identifying the causes of changes in the state of the enterprise. Therefore, a VBA application based on Microsoft Excel was developed, aimed at simplifying and speeding up the analysis. The application is easy to use and has a simple interface. In the finished form, the user enters indicators from the balance sheet. The program itself performs the analysis in the M.S. Excel developer mode. However, it was not possible to include all areas of study in the program, since, in some aspects of the analysis, the presence of the human factor is mandatory.

\section{RESULTS AND DISCUSSIONS}

In Russian and international practice, various mathematical models distinguished that make it possible to assess the probability of the risk of financial insolvency. The easiest to use is the model of Altman, Lis, Tuffler, and others. Domestic scientists and economists are also developing methodological tools to simulate the likelihood of bankruptcy of an organization. Separately, among them, we can distinguish the model of O.P. Zaitseva, V.V. Kovalev, the development by scientists of the Irkutsk State Economic Academy, R.S. Sayfulin and G.G. Kadykov.

The British scientist R. Tuffler proposes an integrated four-factor model based on the determination of bankrupt and solvent companies [8]. This sample ratio calculation is typical in identifying some critical dimensions of a corporation's activities in profitability, matching working capital, financial risk, and liquidity [11]. Combining these indicators and their single code causes the model to reproduce an accurate picture of the financial condition [5].

The R. Lis model, based on E. Altman's models, is closer to Russian reality because of the factors used in it, which is its undoubted advantage. However, during the analysis, this model reflects overestimated estimates, since there is a significant impact on sales profit, not considering the tax impact.

W. Beaver proposed a mathematical model to assess the likelihood of bankruptcy based on the experience of 158 companies over ten years. During this period, $50 \%$ of the observed firms went bankrupt. The rest continued to function [7].

The method of the reference enterprise gives an accurate idea of the current financial condition of the company at the bankruptcy stage. The results of the analysis by this technique are in the Table. 1.

Table 1: The final rating of the financial condition "XXX"

\begin{tabular}{|c|c|c|c|c|c|c|c|c|c|c|}
\hline \multirow{2}{*}{$\begin{array}{c}\text { Financial Results for the } \\
\text { period of } \\
01 / 01 / 16-31 / 12 / 18\end{array}$} & \multicolumn{10}{|c|}{ Financial position on 31.12.2019 } \\
\hline & $\sum$ & $\&$ & $\varangle$ & $\stackrel{\text { Aै }}{\text { A }}$ & $\ddot{\oplus}$ & 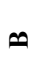 & U & U & U & a \\
\hline Excellent (AAA) & & & & & & - & & & & \\
\hline Perfect (A.A.) & & & & & & - & & & & \\
\hline Good (A) & $\cdot$ & - & $\cdot$ & - & $\cdot$ & $\mathbf{V}$ & $\cdot$ & $\cdot$ & - & $\cdot$ \\
\hline Positive (BBB) & & & & & & $\bullet$ & & & & \\
\hline Normal (B.B.) & & & & & & - & & & & \\
\hline Satisfactory (B) & & & & & & - & & & & \\
\hline Poor (CCC) & & & & & & - & & & & \\
\hline Bad (S.S.) & & & & & & $\bullet$ & & & & \\
\hline Nasty (C) & & & & & & $\bullet$ & & & & \\
\hline Critical (D) & & & & & & - & & & & \\
\hline
\end{tabular}

According to the results of the analysis, the following results were: financial condition "XXX" -300 points, average; results of activity during the analyzed period -+981 thousand rubles. According to the rating scale, these are B (good position) and A (good effects). These estimates are made considering the values of key indicators at the end of the analyzed period. Based on these estimates, the final rating estimate of the financial condition of the organization is calculated. The economicsituation was rated B.B. - average, but prone to worsening financial results. 
The rating "B.B." reflects the financial condition of the organization, in which the bulk of the indicators fit into the normative values. Organizations with such a rating can be considered partners in the relationship with which a prudent approach to risk management is necessary. An organization may qualify for loans, but the decision largely depends on an analysis of additional factors.

Of course, the diagnosis of bankruptcy is essential for the organization, as it must know its bottlenecks to take timely crisis management measures. The assessment of the results of the potential bankruptcy using the models of E. Altman, R. Tuffler, and R. Lis is presented for three large organizations of the Krasnodar Territory.

The probability of bankruptcy of organizations is determined as follows:

- if the value of $Z<1.230$, then this is a sign of a high probability of bankruptcy, while the amount of $Z>1.230$ or more indicates a low probability of default (E. Altman model);

- if the value of $Z<0.2$, then bankruptcy is more than likely, and if the value of $Z>0.3$ - this indicates favorable long-term prospects (R. Tuffler's model);

- if the value $\mathrm{Z}$ is $<0.037$, then the probability of bankruptcy is high, and if $Z>0.037$, this indicates a low risk of default $(R$. Lis model).

Using the above formulas, we assess the potential bankruptcy of the studied organizations in Table 2 .

Table 2: Assessment of the potential bankruptcy of the studied organizations based on multivariate models

\begin{tabular}{|c|c|c|c|c|c|c|c|}
\hline \multirow{2}{*}{ Model } & \multirow{2}{*}{2017} & \multirow{2}{*}{2018} & \multirow{2}{*}{2019} & \multirow{2}{*}{ Recommended Value } & \multicolumn{3}{|c|}{ Deviation (+. -) 2019 from } \\
\hline & & & & & 2017 & 2018 & the norm \\
\hline \multicolumn{8}{|c|}{ AgrofirmYubileinaya LLC } \\
\hline Altman' & 1.817 & 1.432 & 1.167 & $>1.230$ & -0.650 & -0.265 & -0.063 \\
\hline Tuffler' & 1.307 & 0.744 & 0.405 & $>0.300$ & -0.902 & -0.339 & 0.105 \\
\hline Lis' & 0.062 & 0.052 & 0.038 & $>0.037$ & -0.024 & -0.014 & 0.001 \\
\hline \multicolumn{8}{|c|}{ JSC "Agricultural Association "Kuban" } \\
\hline Altman' & 1.481 & 1.441 & 1.217 & $>1.230$ & -0.264 & -0.224 & -0.013 \\
\hline Tuffler' & 0.534 & 0.486 & 0.433 & $>0.300$ & -0.101 & -0.053 & 0.133 \\
\hline Lis' & 0.055 & 0.048 & 0.048 & $>0.037$ & -0.007 & 0.0 & 0.011 \\
\hline \multicolumn{8}{|c|}{ OJSC "IOC "Bratkovsky" } \\
\hline Altman' & 2.045 & 0.765 & 0.670 & $>1.230$ & -1.375 & -0.095 & -0.560 \\
\hline Tuffler' & 1.178 & 0.323 & 0.333 & $>0.300$ & -0.845 & 0.010 & 0.033 \\
\hline Lis' & 0.055 & 0.032 & 0.029 & $>0.037$ & -0.026 & -0.003 & -0.008 \\
\hline
\end{tabular}

From the data in Table 2, it follows that the Altman coefficient in all three studied organizations has negative dynamics and in 2018 is below the theoretically recommended value, which indicates a high risk of bankruptcy of farms. The largest deviation from the criterion value was observed in OJSC "IOC "Bratkovsky"- by 0.560 points.

The results of assessing the potential bankruptcy of the studied organizations using multifactor models are illustrated in Table 3.
Table 3: The assessment results of the potential bankruptcy of the studied organizations according to multifactor models

\begin{tabular}{|c|c|c|c|}
\hline \multirow{2}{*}{ Indicators } & \multicolumn{3}{|c|}{ Bankruptcy probability } \\
\cline { 2 - 4 } & 2017 & 2018 & 2019 \\
\hline \multicolumn{3}{|c|}{ AgrofirmYubileinaya LLC } \\
\hline Altman' coefficient & low & low & low \\
\hline Tuffler' coefficient & \multicolumn{3}{c|}{ low } \\
\hline Lis' coefficient & low & high \\
\hline JSC "Agricultural Association "Kuban" \\
\hline Altman' coefficient & low & low \\
\hline Tuffler' coefficient & \multicolumn{3}{|}{ low } \\
\hline Lis' coefficient & high & high \\
\hline \multicolumn{3}{|c|}{ OJSC "IOC "Bratkovsky" } \\
\hline Altman' coefficient & low & high \\
\hline Tuffler' coefficient & low & low & \\
\hline Lis' coefficient &
\end{tabular}

Summing up, we can conclude that the rating score is an important and useful source of information on a particular company. It helps all potential users to get real information about their partners, to find out their strengths and weaknesses.

One of the results of the assessment is formation rating economic entities by a system of indicators of their financial condition. Getting information allows you to identify specific trends in development, to understand the future strategy of the enterprise. Businesses should regularly monitor their ratings to determine their position, maintain their image, evaluate their effectiveness, and select a plan for further development. It will prevent the bankruptcy of a legal entity. Despite the satisfactory financial situation, the organization does not exclude the possibility of a transition to bankruptcy proceedings in the future.

The results of our preliminary studies suggest that the most rational management decision in organizations to reduce the risk of bankruptcy is the introduction of factoring, which accelerates the turnover of working capital and reduces the need for them. It is because financing through factoring does not make the company a borrower, unlike bank lending. At the same time, no accounts payable appear in the balance sheet of the company.

\section{CONCLUSION}

To date, various models for assessing bankruptcy risks are used. However, it is noted that a limited number of indicators are taken when using them. This fact indicates the absence of consideration of the impact on the financial condition of the company of other important indicators. Accordingly, there is a need to develop a methodology that reflects the financial situation closest to reality. However, creating a universal method suitable for different economic areas is very doubtful, since the difference between the indicators of one sphere from another is too great.

The initiator of a conflict-free resolution of problems can be any of the parties. An amicable agreement is concluded by the mutual understanding of all participants in the procedure. If a peace agreement was concluded, then the parties to the agreement terminate the bankruptcy procedure [7]. 
Thus, conducting bankruptcy proceedings is a rather complicated, multi-stage process, which requires interdisciplinary knowledge and skills that are mastered by future arbitration managers in the framework of a unique retraining program.

For a favorable outcome of a bankruptcy case with minimal costs, it is better to prepare for the procedures in advance, involving experts and professional anti-crisis managers with superior knowledge and the necessary experience.

The creation of your application for analysis is due to the use of financial analysis programs is not always practical, since they view the organization as in an already dysfunctional state and are aimed at treating or liquidating the organization. It is not known what position the organization is in before analysis. The effectiveness of this analysis as an assessment of liquidity, financial stability, diagnostics to bankruptcy and evaluation of net assets and liabilities is unmistakably a fact.

\section{REFERENCES}

1. A.P. Gusev. Bankruptcy: a guide for an entrepreneur, Rostov n/a: Phoenix, 2014, pp. 34-36.

2. A.I. Goncharov and S.A.Zinchenko. Prevention of bankruptcy of a commercial organization, Methodology and legal mechanisms, M, Jurisprudence, 2016, pp. 347-350.

3. E.V. Alekseeva. Insolvency (bankruptcy) of legal entities, M. Prospect, 2018, pp. 23-24.

4. E.P. Gubina and S.A. Karelina. Legal regulation of economic relations. Insolvency (bankruptcy), $\mathrm{M}$. Statute, 2018, pp. 187-190.

5. Aaron Don M. Africa, Francis Xavier Asuncion, Raymund Miguel Francisco A. Munchua, Janos Lance Tiberio, Joshua Vincent Ligayo, Raine Mattheus Manuel.PCB/Microstrip Antenna Design and Simulation, International Journal of Emerging Trends in Engineering Research, 2019. Vol. 7(8), pp. 157-162.

6. E.V. Novoselov. Bankruptcy: A Guide to Decision Making, M. Justicinform, 2014, pp. 232-236.

7. D. Omar. Analysis of the financial condition of the company is the essence of financial analysis and its Purpose,Statistics, accounting and audit, 2011, Vol. 1(40). pp. 33-36.

8. G.E. Kontsevich, A.K. Shanko, V.K. Shanko. The place and role of accounting in the analysis of the financial condition of the organization, New science: Current state and development paths, 2016. Vol. 5(1). pp. 106-108.

9. M. Jaya Bhaskar, Y. Venkatesh, R. Sai Bhaskar Pranai, M. Rohith.Face Recognition for Attendance Management, International Journal of Emerging Trends in Engineering Research, 2020. Vol. 8(4), pp. 964-968.

10. A.A. Starkova, and M.N. Smagina. The role of financial condition in analysis of enterprise activity, Bulletin of scientific conferences, 2016. Vol. 10-6(14). pp. 174-176.

11. E.S. Malyukova. Key organizations financial indicators, Synergy of Sciences, 2017, Vol. 1(18), pp. 336-346.
12. Anthony Nugraha and Seng Hansun. Fiturebot.C.S. Chatbot Application using Nazief-Adriani Algorithm, International Journal of Emerging Trends in Engineering Research, 2020. Vol. 8(2), pp. 350-354. 